\title{
Kinetics of Utilization of Organic Substrates by Mycoplasma mycoides subsp. mycoides in a Salts Solution: a Flow-microcalorimetric Study
}

\author{
By R. J. MILES, ${ }^{1 *}$ A. E. BEEZER ${ }^{2}$ AND D. H. LEE ${ }^{1}$ \\ ${ }^{1}$ Department of Biological Sciences and ${ }^{2}$ Department of Chemistry, Chelsea College, \\ University of London, Hortensia Road, London SWIO OQR, UK
}

(Received 30 October 1984 ; revised 10 April 1985)

\begin{abstract}
The metabolism of various organic substrates by suspensions of Mycoplasma mycoides subsp. mycoides in a salts solution was followed by microcalorimetry. Enthalpy changes associated with metabolism were in good agreement with theoretical values. Substrate utilization showed Michaelis kinetics, allowing saturation constants $\left(K_{\mathrm{m}}\right)$ and maximum specific rates of substrate utilization $\left(V_{\max }\right)$ to be determined. In cells grown on a complex medium containing glucose, $K_{\mathrm{m}}$ values were: glucose, fructose, $N$-acetylglucosamine, glycerol and pyruvate, $<5 \mu \mathrm{M}$; lactate, $20 \mu \mathrm{M}$; glucosamine, $130 \mu \mathrm{m}$, and mannose, $1 \mathrm{mM}$. Values of $V_{\max }$ for glycerol, pyruvate and lactate were similar and approximately twice those for glucose, mannose, glucosamine and $\mathrm{N}$ acetylglucosamine; $V_{\max }$ for fructose was one-quarter of that for glucose. In cells grown on complex medium in which glucose was replaced by mannose, glucosamine or $\mathrm{N}$-acetylglucosamine, $V_{\max }$ and $K_{\mathrm{m}}$ for the respective growth sugars and for glucose were not significantly affected. However, in cells grown in the presence of fructose, $V_{\max }$ for fructose increased to the value observed for glucose. It is suggested that $M$. mycoides is adapted to, and is constitutive for, the utilization of a single sugar (glucose), and a single amino sugar ( $N$-acetylglucosamine), but that in the presence of fructose a fructose-utilizing pathway is induced.
\end{abstract}

\section{INTRODUCTION}

Mycoplasma mycoides subsp. mycoides is the causative agent of contagious bovine pleuropneumonia, a disease of economic significance in many African countries, India and elsewhere (Gourlay \& Howard, 1979).

A fermentable sugar is essential for the growth of $M$. mycoides (Rodwell \& Mitchell, 1979), which has been reported to use glucose, fructose, mannose, maltose, trehalose, glycogen or starch (Rodwell \& Mitchell, 1979; Smith \& Oliphant, 1982). However, in a medium without serum, we have shown that $M$. mycoides subsp. mycoides strain $T_{1}$ utilizes glucose, mannose and fructose, and that in pig or calf serum medium the apparent utilization of di- and polysaccharides of glucose is due to hydrolysis to glucose by serum enzymes (Miles \& Lee, 1983). Glucosamine and $N$-acetylglucosamine may also replace glucose in media for $M$. mycoides strain $\mathrm{T}_{1}$ (Miles \& Lee, unpublished results). There is evidence that sugar transport in Mycoplasma spp. involves a phosphoenolpyruvate-dependent phosphotransferase system (PTS; Cirillo \& Razin, 1973).

Resting cell suspensions of $M$. mycoides oxidize glucose, glycerol, pyruvate and lactate quantitatively to acetate and carbon dioxide (Rodwell \& Rodwell, 1954); intermediate compounds of the tricarboxylic acid cycle, sugars other than glucose, fructose and mannose, and amino acids other than threonine and serine are not metabolized (Rodwell, 1967). Glycerol oxidation requires the presence of catalase and involves a flavoprotein-mediated oxidation to triose phosphate with concomitant formation of hydrogen peroxide (Rodwell, 1967).

Abbreviation: PTS, phosphotransferase system. 
The measurement of heat production is a direct and sensitive method of observing the metabolic processes of micro-organisms, and microcalorimetry has been widely applied in studies of microbial growth, cell-drug interactions, etc. (Spink \& Wadso, 1976; Beezer, 1980); it may be of potential value in growth studies of mycoplasmas (Ljungholm et al., 1976).

In the work reported here we have investigated the effect on heat output of adding single substrates to $M$. mycoides strain $T_{1}$ grown in the presence of various sugars and suspended in a salts solution. The calorimetric data should allow determination of (1) the effect of substrate concentration on its rate of utilization, (2) maximum rates of substrate utilization, (3) associated enthalpy changes and (4) whether growth on a particular sugar leads to increased rates of utilization of that sugar, i.e. whether adaptation takes place. To ensure comparability between experiments the cells used in this study were stored in liquid nitrogen and for each growth-sugar were from a single batch of cells. The advantages of using liquid nitrogen stored cells in studies of this kind have been discussed previously (Beezer et al., 1976).

\section{METHODS}

Organisms. Mycoplasma mycoides subsp. mycoides strain $\mathrm{T}_{1}$ was kindly provided by Dr G. R. Smith, Nuffield Laboratories of Comparative Medicine, Regents Park, London, UK. This strain is a mild or attenuated strain and is widely used as a live vaccine in East Africa (Hudson, 1971).

Media. The growth medium consisted of ( $\mathrm{g} \mathrm{l}^{-1}$ except where stated): tryptose (Oxoid), 25; yeast extract (Oxoid), 5; glycerol, $5 ; \mathrm{Na}_{2} \mathrm{HPO}_{4}, 8 \cdot 1 ; \mathrm{KH}_{2} \mathrm{PO}_{4}, 1 \cdot 9 ; \mathrm{NaCl}, 2 \cdot 5$; benzylpenicillin, $0 \cdot 125$; glucose, 5 ; pig serum (Gibco, UK) inactivated at $56^{\circ} \mathrm{C}$ for $30 \mathrm{~min}, 100 \mathrm{ml} \mathrm{I}^{-1}$. Benzylpenicillin and glucose were sterilized by membrane filtration (pore size $0.22 \mu \mathrm{m}$ ); other components, except serum, were autoclaved after adjustment of the pH value to 7.6. The final $\mathrm{pH}$ value was $7 \cdot 6$. Where appropriate, glucose was replaced by filter-sterilized mannose, fructose, glucosamine or $N$-acetylglucosamine. The characteristics of growth of $M$. mycoides in this medium have been described elsewhere (Miles, 1983).

Viable counts. A surface drop-plate method (Postgate, 1969) was used for viable counts, with a solid medium of blood agar base (Oxoid), $30 \mathrm{~g} \mathrm{l}^{-1}$; glycerol, $10 \mathrm{~g} \mathrm{l}^{-1}$; pig serum, $240 \mathrm{ml} \mathrm{l}^{-1}$ and benzylpenicillin, $0 \cdot 125 \mathrm{~g} \mathrm{l}^{-1}$. Dilutions were prepared in one-quarter strength Ringer's solution $\left(\mathrm{NaCl}, 39 \mathrm{mM} ; \mathrm{KCl}, 1.4 \mathrm{mM} ; \mathrm{CaCl}_{2}, 1.1 \mathrm{~mm}\right.$; $\mathrm{NaHCO}_{3}, 0.60 \mathrm{~mm} ; \mathrm{pH} \mathrm{7.0)}$. Plates were incubated at $37^{\circ} \mathrm{C}$ for $7 \mathrm{~d}$.

Harvesting and storage of inocula. Samples $(1 \mathrm{ml})$ of a liquid nitrogen stored stationary phase $(72 \mathrm{~h})$ glucosegrown culture were inoculated into $220 \mathrm{ml}$ volumes of medium in $250 \mathrm{ml}$ disposable tissue culture bottles (Sterilin). After $48 \mathrm{~h}$ static incubation at $37^{\circ} \mathrm{C}$, the cells were centrifuged $(14000 \mathrm{~g}, 30 \mathrm{~min})$ at $4{ }^{\circ} \mathrm{C}$, resuspended in half their original culture volume of one-quarter strength Ringer's solution containing $1.5 \mathrm{M}$-glycerol, and dispensed in $2 \mathrm{ml}$ samples into $12 \times 35 \mathrm{~mm}$ polyproplyene screw-in cap ampoules (Sterilin). Ampoules were cooled to $-90^{\circ} \mathrm{C}$ at a rate of $15^{\circ} \mathrm{C} \mathrm{min}{ }^{-1}$, and then cooled rapidly to $-196^{\circ} \mathrm{C}$ in liquid nitrogen according to the procedure of Beezer $e t$ al. (1976). At the time of harvesting, cultures had an $\mathrm{OD}_{540}$ (EEL colorimeter) of 0.06 to $0 \cdot 10$ and viable counts of 1 to $2 \times 10^{9}$ c.f.u. $\mathrm{ml}^{-1}$ depending on the growth-sugar. An $\mathrm{OD}_{540}$ of $0 \cdot 10$ was equivalent to $0 \cdot 13 \mathrm{~g}$ dry wt of cells $\mathrm{l}^{-1}$.

Calorimetric incubations. The calorimeter used was a multichannel conduction calorimeter (prototype of the 2277 Bioactivity Monitor, LK B Produkter; Suurkuusk \& Wadso, 1982) operated in the flow-through mode at a flow rate of $20 \mathrm{ml} \mathrm{h}^{-1}$. The volume of the flow cell was $0.6 \mathrm{ml}$ and calibration was by internal heaters. The long-term baseline stability of this instrument is $\pm 0 \cdot 1 \mu \mathrm{W}$ (Suurkuusk \& Wadso, 1982).

Flow lines were disinfected with ethanol $(15 \mathrm{~min})$ and washed with sterile distilled water $(4 \times 15 \mathrm{~min})$. Incubations were done in sterile acid-washed $50 \mathrm{ml}$ glass vessels with air condensers. Vessels were maintained at $37^{\circ} \mathrm{C}$ in a water bath and contained $25 \mathrm{ml}$ of magnetically-stirred medium of composition ( $\left.\mathrm{g} \mathrm{l}^{-1}\right): \mathrm{Na}_{2} \mathrm{HPO}_{4}, 8 \cdot 1$; $\mathrm{KH}_{2} \mathrm{PO}_{4}, 1 \cdot 9 ; \mathrm{NaCl}, 2 \cdot 5 ; \mathrm{MgCl}_{2}, 0.04 ; \mathrm{CaCl}_{2}, 0.03 ; \mathrm{MnCl}_{2}, 0.00015 ; \mathrm{ZnSO}_{4}, 0.001 ; \mathrm{CuSO}_{4} .5 \mathrm{H}_{2} \mathrm{O}, 0.0005 ;$ $\mathrm{FeSO}_{4} .7 \mathrm{H}_{2} \mathrm{O}, 0.001$; benzylpenicillin, $0 \cdot 125$; and $160 \mathrm{U}$ catalase (Sigma C-10) $\mathrm{ml}^{-1}$. After a stable base line had been achieved in this medium, a liquid nitrogen stored ampoule was thawed in a water bath $\left(4 \mathrm{~min}, 37^{\circ} \mathrm{C}\right)$, and $1.5 \mathrm{ml}$ of the contents was centrifuged (MSE Microcentaur; $11000 \mathrm{~g}, 4 \mathrm{~min}$ ), washed and resuspended in $1 \mathrm{ml}$ of the salts solution plus catalase described above, and inoculated into the incubation vessel. In all cases viable counts of thawed cell suspensions were $>85 \%$ of those before freezing.

Freshly prepared solutions of substrate were added $1 \mathrm{~h}$ after inoculation unless stated otherwise. No heat effects were observed on adding substrates (at the concentrations used here) to uninoculated salts solution. All experiments were done at least twice.

\section{RESULTS}

The power-time $(p-t)$ curve of glucose grown cells inoculated into salts plus catalase medium is shown in Fig. 1. There was an immediate peak of power $(5 \cdot 0$ to $6 \cdot 0 \mu \mathrm{W})$, followed by a decline to a low value (approximately $0.5 \mu \mathrm{W}$ ) which was maintained for several hours. There was no 


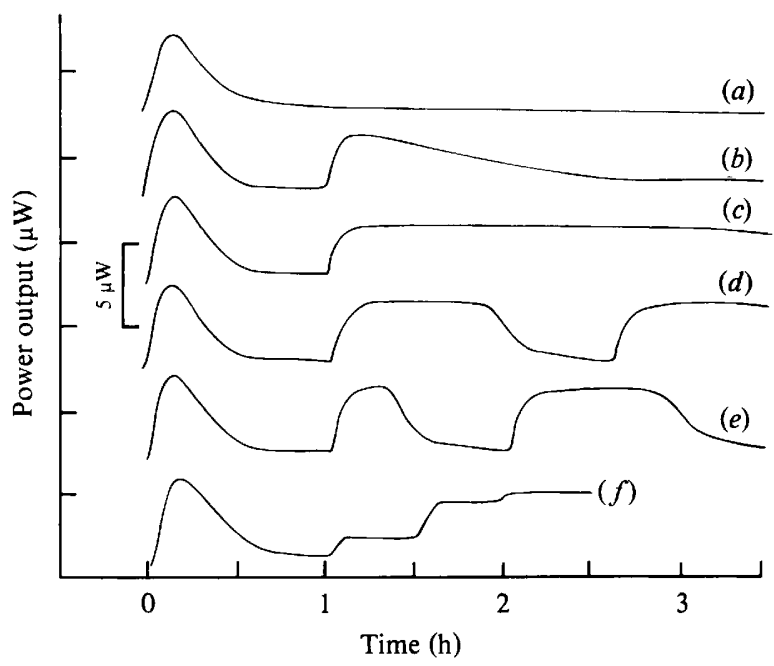

Fig. 1. Representative $p-t$ curves to show the effect of glucose and mannose on the power output of glucose-grown cells suspended in salts solution at a concentration of $6.7 \mathrm{mg}$ dry $\mathrm{wt}^{-1}$. Cells were inoculated at $0 \mathrm{~h}$. Curve $(a)$ was the control (no sugar added). Glucose additions were $(b) 20 \mathrm{~mm}$ at $1 \mathrm{~h}$, (c) $2 \mathrm{mM}$ at $1 \mathrm{~h},(d) 20 \mu \mathrm{M}$ at $1 \mathrm{~h}$ and $2 \mathrm{mM}$ at $2.5 \mathrm{~h}$ and (e) $10 \mu \mathrm{M}$ at $1 \mathrm{~h}$ and $20 \mu \mathrm{M}$ at $2 \mathrm{~h}$. Mannose additions were $(f) 0.4 \mathrm{~mm}$ at $1 \mathrm{~h}, 0.8 \mathrm{~mm}$ at $1.5 \mathrm{~h}$ and $2 \mathrm{~mm}$ at $2 \mathrm{~h}$.

change in viable count during the first $6 \mathrm{~h}$ of incubation. We interpret this peak as being due to metabolism of residual substrates, either intracellular, or extracellular and not removed during washing of cells after thawing. Glycerol may be the most important residual substrate as (1) it was used as a cryoprotectant during freezing at a high concentration (1.5 $\mathrm{M})$, (2) maximum power output was similar to that after addition of glycerol and (3) the decline in power from the peak was similar to that after exhaustion of added glycerol.

After the decline of power to $0.5 \mu \mathrm{W}$, addition of glucose to a concentration of $2 \mathrm{~mm}$ resulted in a rise in power output to a plateau value $(3.0 \mu \mathrm{W})$ which was maintained for approximately $2 \mathrm{~h}$ before a gradual decline. At a higher concentration of glucose $(20 \mathrm{~mm})$ the decline was more rapid and occurred earlier (Fig. 1, Table 1). Plateau values were observed from approximately $8 \mathrm{~min}$ after addition of glucose; this time will reflect the time required for glucose to reach the calorimeter ( $4 \mathrm{~min}$ ) and for the concentration in the calorimeter vessel to rise, as well as any time required for the cells to adapt to a maximum rate of metabolism.

When the initial concentration of added glucose was reduced to 20 or $10 \mu \mathrm{M}$, the plateau value reached was not reduced. However, 1.5 and $1 \mathrm{~h}$ respectively, after the addition of glucose, power output had declined to the value observed before addition (Fig. 1). Further addition of glucose caused power output to return to the plateau value (Fig. 1). It is clear, therefore, that after addition of small quantities of glucose the return of power output to that observed before addition was due to exhaustion of glucose.

For the period of glucose utilization (initial glucose concentration 10 or $20 \mu \mathrm{M}$ ), total heat production $\left(Q_{T}\right)$, and hence the enthalpy change for glucose metabolism $\left(\Delta H_{\text {met }}\right)$, was estimated by graphical integration of the area under the $p-t$ curve, assuming that power output at the plateau value started at the time of addition of glucose. If it is further assumed that the quantity of heat evolved $\left(Q_{t}\right)$ at any time $(t)$ is proportional to the glucose consumed, then glucose concentration at that time will be $\left(Q_{T}-Q_{t}\right) S_{i} / Q_{T}$, where $S_{i}$ is the initial glucose concentration. Also, the rate of substrate utilization $(V)$ at any time will be $\mathrm{d} Q . S_{i} / Q_{T} . \mathrm{d} t$, where $\mathrm{d} Q / \mathrm{d} t$ is power output.

Using these relationships, double reciprocal plots of glucose concentration against rate of glucose utilization were made (e.g. Fig. 2). These plots were linear in the range 0 to $10 \mu \mathrm{M}$, suggesting that glucose metabolism follows Michaelis kinetics, and allowing determination (Table 2) of a maximum rate of glucose utilization $\left(V_{\max }\right)$ from the intercept on the ordinate axis $\left(1 / V_{\max }\right)$, and a saturation constant $\left(K_{\mathrm{m}}\right)$ from the intercept on the abscissa $\left(-1 / K_{\mathrm{m}}\right)$. 


\section{Table 1. Increase in power output and specific rate of substrate utilization after addition of} various substrates to $M$. mycoides

Glucose-grown cells stored in liquid nitrogen were inoculated into a salts solution (final cell concentration $6.7 \mathrm{mg}$ dry wt $\mathrm{l}^{-1}$ ), and after $1 \mathrm{~h}$ substrate was added. In calculating the rate of substrate utilization, experimentally determined values of $\Delta H_{\text {met }}$ (Table 2) were used; it was assumed that the values of $\Delta H_{\text {met }}$ for mannose and glucosamine were the same as for glucose and $N$-acetylglucosamine respectively.

\begin{tabular}{|c|c|c|c|c|c|}
\hline \multirow[b]{2}{*}{ Substrate } & \multirow{2}{*}{$\begin{array}{c}\text { Concn } \\
(\mathrm{mM})\end{array}$} & \multicolumn{3}{|c|}{$\begin{array}{l}\text { Increase in power output }(\mu \mathrm{W}) \\
\text { after substrate addition }\end{array}$} & \multirow{2}{*}{$\begin{array}{c}\text { Rate of substrate } \\
\text { utilization at } 0.2 \mathrm{~h} \\
{\left[\mu \mathrm{mol}(\mathrm{g} \text { dry wt cells })^{-1} \mathrm{~min}^{-1}\right]}\end{array}$} \\
\hline & & $0.2 \mathrm{~h}$ & $1 \cdot 0 \mathrm{~h}$ & $2 \cdot 0 \mathrm{~h}$ & \\
\hline Glucose & $\begin{array}{r}20 \\
2\end{array}$ & $\begin{array}{l}3 \cdot 1 \\
3 \cdot 0\end{array}$ & $\begin{array}{l}1 \cdot 2 \\
3 \cdot 0\end{array}$ & $\begin{array}{l}0 \cdot 5 \\
2 \cdot 4\end{array}$ & $\begin{array}{l}42 \\
41\end{array}$ \\
\hline Fructose & $\begin{array}{r}20 \\
2\end{array}$ & $\begin{array}{l}3 \cdot 0^{*} \\
1 \cdot 4^{*}\end{array}$ & $\begin{array}{l}1 \cdot 0 \\
1 \cdot 1\end{array}$ & $\begin{array}{l}1 \cdot 0 \\
1 \cdot 1\end{array}$ & $\begin{array}{l}40^{*} \\
18^{*}\end{array}$ \\
\hline Mannose & $\begin{array}{r}20 \\
2\end{array}$ & $\begin{array}{l}4 \cdot 2 \\
3 \cdot 5\end{array}$ & $\begin{array}{l}4 \cdot 1 \\
3 \cdot 2\end{array}$ & $\begin{array}{l}4 \cdot 0 \\
3 \cdot 0\end{array}$ & $\begin{array}{l}57 \\
48\end{array}$ \\
\hline Glucosamine & 2 & $3 \cdot 5$ & 3.5 & $2 \cdot 5$ & 49 \\
\hline$N$-Acetylglucosamine & 2 & $3 \cdot 2$ & 3.0 & $3 \cdot 0$ & 45 \\
\hline Glycerol & $\begin{array}{r}40 \\
4\end{array}$ & $\begin{array}{l}6 \cdot 3 \\
6 \cdot 3\end{array}$ & $\begin{array}{l}6 \cdot 3 \\
6 \cdot 2\end{array}$ & $\begin{array}{l}6 \cdot 3 \\
6 \cdot 2\end{array}$ & $\begin{array}{l}124 \\
124\end{array}$ \\
\hline Pyruvate & 4 & $2 \cdot 2$ & $2 \cdot 2$ & $2 \cdot 1$ & 116 \\
\hline Lactate & $\begin{array}{l}4 \\
0 \cdot 4\end{array}$ & $\begin{array}{r}10 \cdot 5 \\
3 \cdot 5\end{array}$ & $\begin{array}{l}5 \cdot 6 \\
3 \cdot 5\end{array}$ & $\begin{array}{l}2 \cdot 4 \\
3 \cdot 4\end{array}$ & $\begin{array}{l}357 \\
119\end{array}$ \\
\hline
\end{tabular}
text).

* Measured at the transient peak of power $(0.15 \mathrm{~h})$, and probably due to glucose contamination of fructose (see

When glucose was replaced by $2 \mathrm{mM}-N$-acetylglucosamine, glucosamine or mannose, or $4 \mathrm{mM}$ glycerol or sodium pyruvate, power output reached a plateau value which was comparable with that obtained for $2 \mathrm{~mm}$-glucose and which was maintained for $1 \mathrm{~h}$ or more (Table 1 ).

Fructose ( 2 and $20 \mathrm{~mm}$ ) gave a transient peak of power followed by a low plateau (Table 1 ). When, during this plateau, further equal additions of fructose were made, similar transient peaks followed before power output returned to the same plateau value. These transient peaks were attributed to glucose contamination of fructose which, although below $0.05 \%(w / w)$, would be significant in this system. The low plateau of power output was attributed to fructose metabolism and was obtained at low concentrations of fructose $(200$ and $20 \mu \mathrm{M})$ where the transient peak of power was absent.

Sodium L-lactate ( $4 \mathrm{mM})$ gave a peak of power output $(10.5 \mu \mathrm{W})$, which was greater than that for other substrates, followed by a gradual decline (Table 1); however, lower levels of sodium lactate $(0.4 \mathrm{mM})$ gave plateaus of power comparable with that for glucose.

As with glucose, low concentrations of $N$-acetylglucosamine $(20 \mu \mathrm{M})$ or glycerol, sodium lactate or sodium pyruvate $(40 \mu \mathrm{M})$ gave $p-t$ curves which showed a plateau of power followed by a decline to the power output obtained before substrate addition. This decline was due to substrate exhaustion, as further addition of substrate caused power output to return to the plateau value; thus $Q_{T}$ and hence $\Delta H_{\text {met }}$ could be determined in the same way as for glucose (Table 2). Also, double reciprocal plots of substrate concentration against rate of substrate utilization were linear (Fig. 2), allowing determination of $K_{\mathrm{m}}$ and $V_{\max }$ (Table 2).

The rate of utilization of fructose was too low to allow determination of $Q_{T}, K_{\mathrm{m}}$ or $V_{\max }$ by the procedure used for glucose. However, by doubling the organism concentration, plateau values of power output of $0.9,1.8$ and $2.4 \mu \mathrm{W}$ were obtained at fructose concentrations of 2,10 and $200 \mu \mathrm{M}$ respectively, thus allowing estimation of $K_{\mathrm{m}}$ and $V_{\max }$ values for fructose (Table 2). In calculating $V$, it was assumed that the ratio of $S_{i} / Q_{T}$ was the same as that observed in fructosegrown cells (see below).

In contrast to the results obtained with other sugars, the effect of low concentrations $(20 \mu \mathrm{M})$ of mannose or glucosamine on power output was barely detectable. With these sugars, plateau 


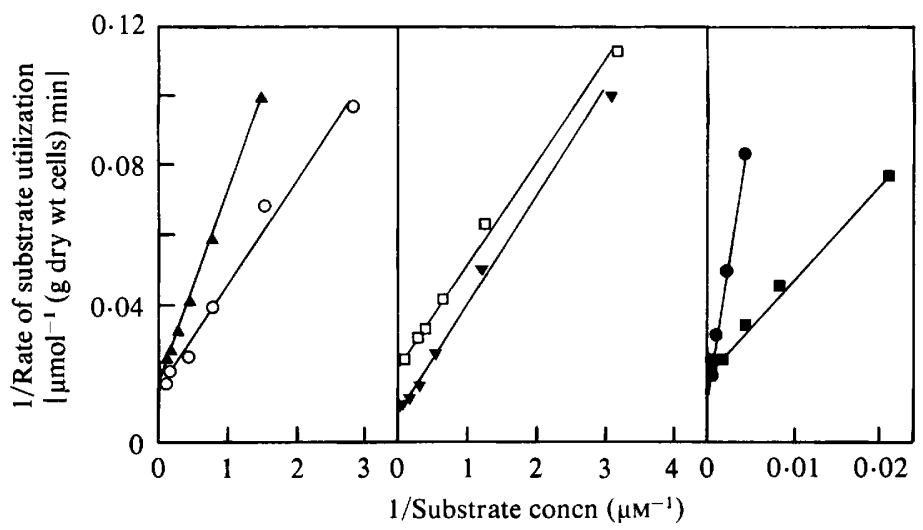

Fig. 2. Double reciprocal plots of substrate concentration versus rate of substrate utilization by cells suspended in a salts solution. The data were derived, as described in the text, from representative $p-t$ curves of glucose-grown cells with glucose $(\bigcirc), N$-acetylglucosamine $(\square)$, glycerol ( $\nabla)$, mannose (O) and glucosamine ( $\boldsymbol{\square})$ as substrates, and of fructose-grown cells with fructose $(\boldsymbol{\Delta})$ as substrate. Correlation coefficients of the linear regression lines were 0.993 with glucose as substrate, and $\geqslant 0.998$ with all other substrates. Similarly derived data for glucose-grown cells with lactate and pyruvate gave correlation coefficients of 0.995 and 0.999 respectively.

Table 2. Kinetics of the utilization of various substrates by M. mycoides in salts solution

Experimental data were derived from $p-t$ curves according to the methods given in the text. In calculating $V_{\max }$ it was assumed that $\Delta H_{\text {met }}$ for fructose was the same in glucose-grown cells as in fructose-grown cells and that $\Delta H_{\text {met }}$ values for mannose and glucosamine were the same as for glucose and $N$-acetylglucosamine respectively. Theoretical values of $\Delta H_{\text {met }}$ are for the conversion of substrate to acetate, $\mathrm{CO}_{2}$ and water (see text), and are derived from published lists of heats of combustion (Weast, 1981).

Sugar used

for cell

growth

Glucose

Fructose

Mannose

$N$-Acetylglucosamine

Glucosamine
Substrate

L-Lactate
Pyruvate
Glycerol
Glucose
Fructose
$N$-Acetylglucosamine
Glucosamine
Mannose
Threonine
Serine

Glucose

Fructose

Glucose

Mannose

Glucose

$N$-Acetylglucosamine

Glucose

Glucosamine

$$
\begin{gathered}
V_{\max } \\
{[\mu \mathrm{mol}(\mathrm{g} d r y} \\
\text { wt cells) } \left.)^{-1} \mathrm{~min}^{-1}\right]
\end{gathered}
$$$$
\underset{(\mu \mathrm{M})}{K_{\mathrm{m}}}
$$$$
\overbrace{\text { Experimental }}^{\Delta H_{\text {met }}\left(\mathrm{kJ} \mathrm{mol}^{-1}\right)}
$$

20
$4 \cdot 3$
$4 \cdot 4$
$2 \cdot 0$
$3 \cdot 7$
$1 \cdot 2$
130
1030
$<40$
$<40$

$\begin{array}{cc}440 & 487 \\ 270 & 283 \\ 760 & 786 \\ 1100 & 1050 \\ \text { ND } & \\ 1120 & \text { NA } \\ \text { ND } & \\ \text { ND } & \\ \text { ND } & \\ \text { ND } & \\ 1070 & 1050 \\ 1140 & 1060 \\ 1000 & 1050 \\ \text { ND } & \\ 1070 & 1050 \\ 1070 & \text { NA } \\ 1120 & 1050 \\ \text { ND } & \end{array}$

ND, Not determinable from the experimental data; NA, not available as products of metabolism unknown.

values of power output were obtained at a number of substrate concentrations by making several additions of substrate during a single calorimetric experiment (e.g. Fig. 1). At the substrate concentrations used $(0.02$ to $10 \mathrm{mM})$, the effect of substrate utilization on substrate concentration was negligible. Double reciprocal plots of substrate concentration against rate of substrate utilization (Fig. 2) allowed calculation of $V_{\max }$ and $K_{\mathrm{m}}$, but because of the low rate of substrate 
utilization at low substrate concentrations $Q_{T}$, and hence $\Delta H_{\text {met }}$, could not be determined. Therefore, in calculating values of $V$ we have assumed that the ratio of $S_{i} / Q_{T}$ is the same (on a molar basis) for mannose and glucosamine as for glucose and $\mathrm{N}$-acetylglucosamine respectively. If this assumption is invalid, the values of $V_{\max }$ (but not $K_{\mathrm{m}}$ ) for mannose and glucosamine (Table 2) are also invalid.

Threonine and serine, which were reported by Rodwell (1967) to be metabolized by resting cell suspensions of $\boldsymbol{M}$. mycoides, both gave plateaus of power output of approximately $0.8 \mu \mathrm{W}$ at a concentration of $40 \mu \mathrm{M}$. These power outputs represented a rate of substrate utilization too low to enable determination of $\Delta H_{\text {met }}$; however, as power output was not increased by increasing threonine or serine concentration to $4 \mathrm{mM}, K_{\mathrm{m}}$ for these amino acids was presumably $<40 \mu \mathrm{M}$.

Cells grown on media in which glucose was replaced by fructose, mannose, glucosamine or $N$ acetylglucosamine gave $p-t$ curves for glucose $(20 \mu \mathrm{M})$ which were similar to those for glucosegrown cells, and from which values of $K_{\mathrm{m}}, V_{\max }$ and $\Delta H_{\text {met }}$ were determined (Table 2). Also, $p-t$ curves representing the utilization of mannose, glucosamine and $\mathrm{N}$-acetylglucosamine by cells grown on these substrates were similar to those of glucose-grown cells and kinetic parameters (Table 2) were determined in the same way. However, the rate of utilization of fructose by fructose-grown cells was significantly greater than by glucose-grown cells. Analysis of $p-t$ curves by the procedure described for glucose allowed determination of $\Delta H_{\mathrm{met}}, K_{\mathrm{m}}$ and $V_{\max }$ for fructose (Table 2, Fig. 2).

In this study, with the exception of the initial peak of power observed before the addition of substrate (Fig. 1), power output in replicate $p-t$ curves varied by no more than $10 \%$. The results shown in Table 1 are from representative $p-t$ curves, and in Table 2 the values given for the kinetic parameters are the means of those determined in three or four replicate experiments; average values were within $5 \%$ of individual values.

\section{DISCUSSION}

Values of $\Delta H_{\text {met }}$ from $p-t$ curves (Table 2) are close to theoretical values for the conversion of glucose, fructose (in fructose-grown cells), pyruvate, lactate and, in the presence of catalase, glycerol to acetate and carbon dioxide. Thus the results support the original observations of Rodwell \& Rodwell (1954) concerning carbohydrate metabolism in $M$. mycoides. The value of $\Delta H_{\text {met }}$ for $N$-acetylglucosamine is close to that for glucose, and presumably reflects the relatively small enthalpy change associated with its hydrolysis, and metabolism of the glucose so produced.

The analysis used here in the determination of $K_{\mathrm{m}}$ and $V_{\max }$ for glucose is a modification of that previously applied to the growth of bacteria (Belaich \& Belaich, 1976; Belaich et al., 1968) and yeast (Schaarschmidt \& Lamprecht, 1978; Murgier \& Belaich, 1971) on various substrates. In these analyses substrate utilization followed Michaelis kinetics, though in some cases there was deviation at high substrate concentration. In the experiments reported here, Michaelis kinetics were also found, though there were deviations at high concentrations of glucose and lactate. The rate of glucose utilization in the presence of saturating concentrations ( 2 and $20 \mathrm{mM}$, Table 1) was only $70 \%$ of $V_{\max }$ derived from Michaelis plots with low concentrations (Table 2), and may possibly be due to inhibitory effects of high glucose concentrations in salts solution; there was a more rapid decline in power output with $20 \mathrm{~mm}$ than with $2 \mathrm{mM}$-glucose (Fig. 1).

A high concentration of lactate ( $4 \mathrm{mM}$ ) added to cells gave peaks of power followed by a decline (Table 1). Rates of substrate utilization at these peaks were up to threefold higher than $V_{\max }$ derived from Michaelis plots with lactate concentrations below $40 \mu \mathrm{M}$ (Table 2). We can offer no explanation for these results, except that high concentrations of lactate may affect cell permeability.

In glucose-grown cells, $K_{\mathrm{m}}$ for the utilization of glucose, fructose, $N$-acetylglucosamine, pyruvate and glycerol was $<5 \mu \mathrm{M}$ (Table 2), which is comparable with the values quoted by Pirt (1975) for energy substrates in growing bacteria. However, mannose and glucosamine gave high values. In glucose-grown cells, values of $V_{\max }$ for glycerol, lactate and pyruvate were similar, as were the values for sugars and amino sugars (Table 2), except the rate for fructose was one- 
quarter of that for glucose. The value of $K_{\mathrm{m}}$ for glucose utilization obtained here $(2 \mu \mathrm{M})$ is considerably less than the estimate of $50 \mu \mathrm{M}$ reported by Cirillo \& Razin (1973) for $M$. mycoides and $M$. gallisepticum; however, in their experiments the lowest initial glucose concentration was $500 \mu \mathrm{M}$.

In cells grown on substrates other than glucose, values of $K_{\mathrm{m}}$ and $V_{\max }$ for glucose were similar to those of glucose-grown cells (Table 2), indicating that the pathway of glucose utilization is constitutive. Values of $K_{\mathrm{m}}$ and $V_{\max }$ for mannose, glucosamine and $N$-acetylglucosamine, in cells grown on mannose, glucosamine and $N$-acetylglucosamine respectively, were also similar to those of glucose-grown cells (Table 2), suggesting that no inducible components exist in the pathways for utilization of these sugars. In cells grown on fructose, however, $V_{\max }$ for fructose utilization increased to a value close to that for glucose. As the growth of glucose-grown cells inoculated into fructose medium was essentially the same as in glucose medium, this adaptation does not reflect selection of a small proportion of mutant cells able to utilize fructose more rapidly, but rather that the pathway for fructose utilization has some inducible component(s).

The high value of $K_{\mathrm{m}}$ for mannose utilization ( $1 \mathrm{mM}$ ), compared to that for glucose utilization $(2 \mu \mathrm{M})$ by both glucose and mannose-grown cells, suggests that mannose is not utilized as an energy substrate by this strain of M. mycoides in vivo. While little information is available on the concentration of specific sugars in the serum and cells of cattle, mannose has not been reported to be present in mammalian blood (Altman \& Dittmer, 1974). It is also possible, as there is a high affinity for $N$-acetylglucosamine $\left(K_{\mathrm{m}} 1 \mu \mathrm{M}\right)$ and a relatively low affinity for glucosamine $\left(K_{\mathrm{m}}\right.$ $130 \mu \mathrm{M})$, that glucosamine might not be used to a significant extent in vivo.

The results suggest, therefore, that $M$. mycoides subsp. mycoides is adapted to, and is constitutive for, the utilization of a single sugar (glucose) and a single amino sugar ( $\mathrm{N}$ acetylglucosamine), but that in the presence of fructose, a fructose-utilizing pathway is induced. It is of interest that, at birth, calves have a high level of blood-fructose (approximately $3 \mathrm{~mm}$ ), but that this concentration declines rapidly to $0 \cdot 15 \mathrm{~mm}$ within $24 \mathrm{~h}$ (Young et al., 1970). In contrast, blood-glucose levels are relatively high ( 2 to $5 \mathrm{mM}$ ) in foetal and adult cattle (Coldman \& Good, 1967; Young et al., 1970).

The high affinity shown by $M$. mycoides for pyruvate and glycerol $\left(K_{\mathrm{m}} 4.3\right.$ and $4.4 \mu \mathrm{M}$ respectively), and perhaps also lactate $\left(K_{\mathrm{m}} 20 \mu \mathrm{M}\right)$, suggests that they are important in vivo. As $V_{\text {max }}$ for these substrates is high, and comparable with that for glucose, they may act as energy sources. Kahane et al. (1978) have suggested that under aerobic conditions ATP might be generated from pyruvate oxidation in $M$. hominis.

The values of $K_{\mathrm{m}}$ and $V_{\text {max }}$ derived here will be determined by the rate-limiting step in the metabolism of each substrate, and are dependent on the substrate used. This suggests that it is transport or some other early metabolic step, unique to the utilization of each substrate, which is rate-limiting. Belaich et al. (1968) argued that the values of $K_{\mathrm{m}}$ and $V_{\max }$, derived from microcalorimetric studies of growing cells, related to transport rather than to subsequent metabolism. If the values of $K_{\mathrm{m}}$ and $V_{\max }$ determined here relate to transport, the low affinity towards mannose and glucosamine might indicate that there are no specific PTS components for these sugars in $M$. mycoides, and that their transport involves glucose- and/or $\mathrm{N}$ acetylglucosamine-specific components. The observed increase in fructose-specific PTS activity in fructose-grown cells as compared to glucose-grown cells of $\boldsymbol{M}$. capricolum (Mugharbil \& Cirillo, 1978) suggests that it is a PTS component(s) of the fructose pathway that is inducible in M. mycoides.

\section{REFERENCES}

Altman, P. L. \& Dittmer, D. S. (1974). Biology Data Book, vol. 3, 2nd edn, pp. 1819-1829. Bethesda, Maryland: Federation of American Societies for Experimental Biology.

BEEZER, A. E. (1980). Biological Microcalorimetry. London: Academic Press.

Beezer, A. E., Newell, R. D. \& Tyrrell, H. J. V. (1976). Application of flow microcalorimetry to analytical problems: the preparation, storage and assay of frozen inocula of Saccharomyces cerevisiae. Journal of Applied Bacteriology 41, 197-207.

Belaich, A. \& Belaich, J. P. (1976). Microcalorimetric study of the anaerobic growth of Escherichia coli: measurement of the affinity of whole cells for various energy substrates. Journal of Bacteriology $125,19-24$ 
Belaich, J. P., Senez, J. C. \& Murgier, M. (1968) Microcalorimetric study of glucose permeation in microbial cells. Journal of Bacteriology 95, 1750 1757.

Cirillo, V. P. \& Razin, S. (1973). Distribution of a phosphoenolpyruvate-dependent sugar phosphotransferase system in mycoplasmas. Journal of Bacteriology 113, 212-217.

Coldman, M. F. \& Good, W. (1967). The distribution of sodium, potassium and glucose in the blood of some mammals. Comparative Biochemistry and Physiology 21, 201-206.

Gourlay, R. N. \& Howard, C. J. (1979). Bovine mycoplasmas. In The Mycoplasmas, vol. 2, pp. 49102. Edited by J. G. Tully \& R. F. Whitcomb. New York: Academic Press.

Hudson, J. R. (1971). Contagious bovine pleuropneumonia. FAO Agricultural Studies, no. 86. Rome: FAO.

Kahane, I., Razin, S. \& Muhlrad, A. (1978). Possible role of acetate kinase in ATP generation in Mycoplasma hominis and Acholeplasma laidlawii. FEMS Microbiology Letters 3, 143-145.

LuUngholm, K., Wadso, I. \& MARDH, P. A. (1976). Microcalorimetric determination of growth of $\mathrm{My}$ coplasmatales. Journal of General Microbiology 96, 283-288.

MiLES, R. J. (1983). Effect of some cultural factors on $T_{1}$ broth vaccine for contagious bovine pleuropneumonia. Tropical Animal Health and Production 15, 144-148.

Miles, R. J. \& LEE, D. H. (1983). Carbohydrate utilisation by Mycoplasma mycoides var mycoides strain $\mathrm{T}_{\mathrm{t}}$ in a medium without serum. Microbios Letters 24, 129-133.

Mugharbil, U. \& Cirillo, V. P. (1978). Mycoplasma phosphoenolpyruvate-dependent sugar phosphotransferase system: glucose-negative mutant and regulation of intracellular cyclic AMP. Journal of Bacteriology 133, 203-209.

Murgier, M. \& Belaich, J. P. (1971). Microcalori- metric determination of the affinity of Saccharomyces cerevisiae for some carbohydrate growth substrates. Journal of Bacteriology 105, 573-579.

PIRT, S. J. (1975). Principles of Microbe and Cell Cultivation, pp. 10-12. Oxford: Blackwell Scientific Publications.

Postgate, J. R. (1969). Viable counts and viability. Methods in Microbiology 1, 611-628.

RoDWELL, A. W. (1967). The nutrition and metabolism of mycoplasma: progress and problems. Annals of the New York Academy of Sciences 143, 88-109.

Rodwell, A. W. \& Mrtchell, A. (1979). Nutrition, growth and reproduction. In The Mycoplasmas, vol. 1, pp. 103-139. Edited by M. F. Barile \& S. Razin. New York: Academic Press.

Rodwell, A. W. \& Rodwell, E. S. (1954). The breakdown of carbohydrates by Asterococcus mycoides, the organism of bovine pleuropneumonia. Australian Journal of Biological Sciences 7, 18-30.

SChaARSCHMIDT, B. \& LAMPREChT, I. (1978). Microcalorimetric study of yeast growth, utilization of different carbohydrates. Thermochimica acta 22, 333-338.

Smith, G. R. \& Oliphant, J. C. (1982). Some in vitro characters of the subspecies of Mycoplasma mycoides. Journal of Hygiene 89, 521-527.

SPINK, C. \& WAdSO, I. (1976). Calorimetry as an analytical tool in biochemistry and biology. In Methods in Biochemical Analysis, vol. 23, pp. 1-159. Edited by D. Glick. New York: Wiley-Interscience. SuURKUUSK, J. \& WADSO, I. (1982). A multichannel microcalorimetry system. Chemica scripta 20, 155163.

WEAST, R. C. (1981). Handbook of Chemistry and Physics, 62nd edn, pp. D251-D257. Boca Raton, Florida: Chemical Rubber Company.

Young, J. W., Otchere, E. O., Trenkle, A. \& JACOBSON, N. L. (1970). Effect of age on glucose, reducing sugars and plasma insulin in blood of milkfed calves. Journal of Nutrition 100, 1267-1274. 